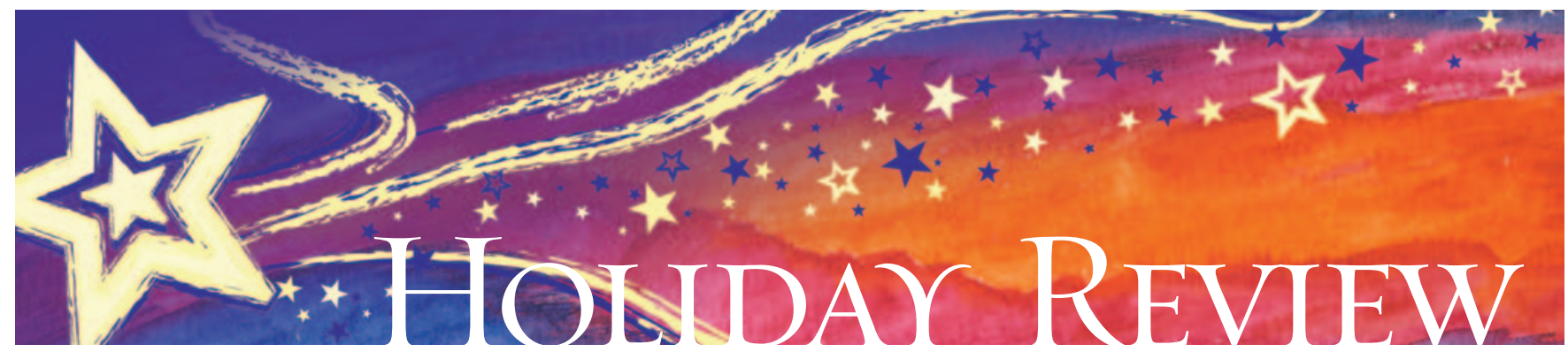

\title{
Auscultations
}

\section{Duty of care to the undiagnosed patient: Ethical imperative, or just a load of Hogwarts?}

\begin{abstract}
With the restoration of You-Know-Who to full corporeal form, the practice of the dark arts may lead to multitudes being charmed, befuddled and confounded. At present, muggle ethics dictate that aid may be rendered in a life- or limb-threatening situation, but the margins are blurred when neither is at stake. Muggle and wizard healers, fearful of being labelled ambulance chasers, may shy away from approaching those who remain blissfully unaware of their illnesses. We describe 4 case studies in which we intervened as muggle healers, to salutary effect. The afflicted were healed or helped, without bringing the weight of the Ministries of Magic or Magical Healing upon us. We advocate a spirit of cooperation between muggle and magical folk, mindful of the strengths that the healing arts from each community have to offer. As long as the intent is beneficent, healers or even the wizard or muggle on the street may intervene and render aid to the afflicted.
\end{abstract}

A lthough the muggle world has, to date, remained blissfully ignorant of events taking place in the wizarding world, the chronicles of "the boy who lived" by the muggle Rowling $^{1-6}$ have alerted the cognoscenti, primarily muggle children and child-like muggles, to the dangers ahead for us all. The combined $\infty$ alarum raised has, however, largely been ignored,

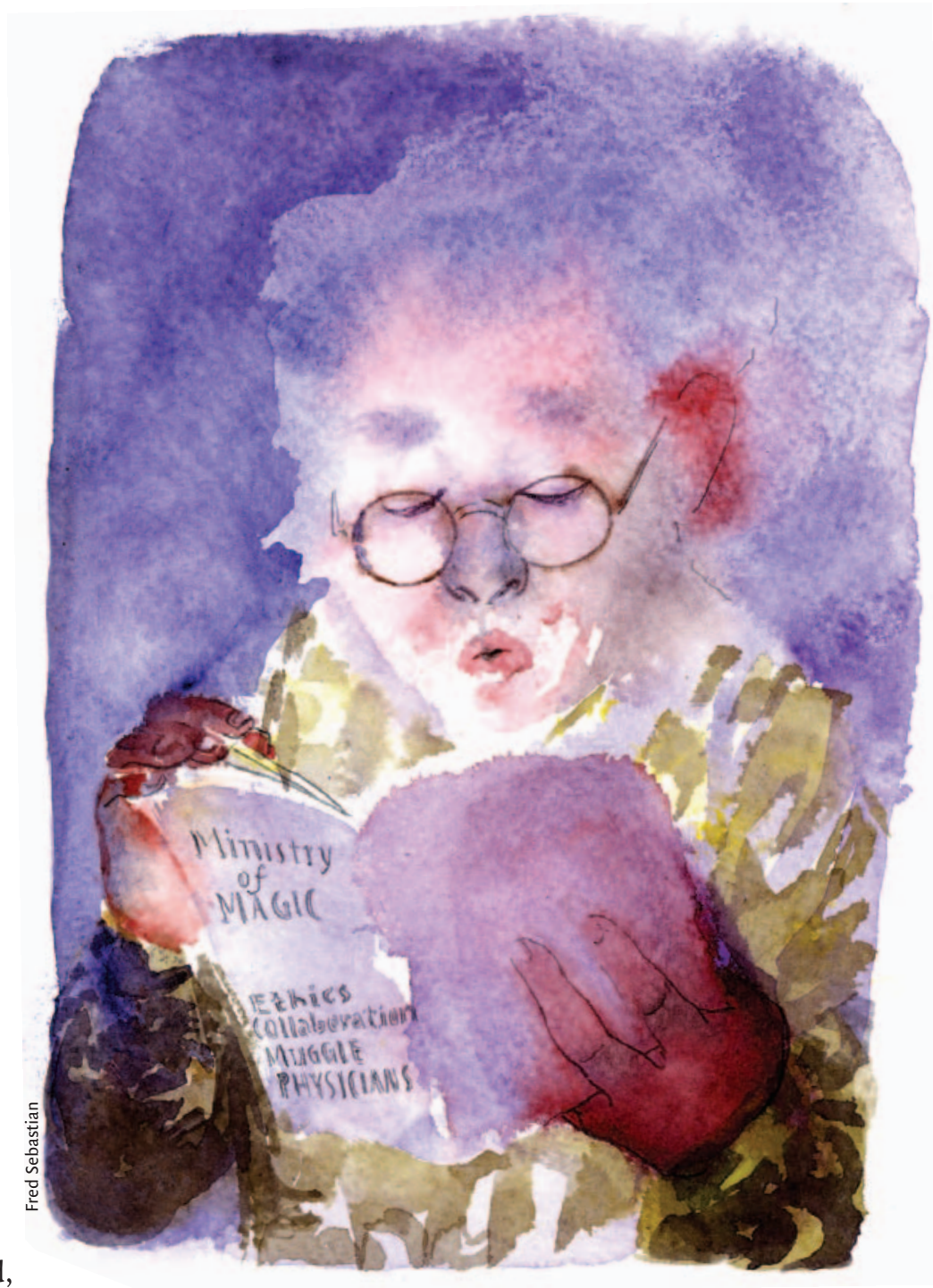
thanks to the ill-advised attempts by the Ministry of Magic to downplay the dangers associated with the return of He-Who-Must-Not-Be-Named (You-Know-Who, henceforth abbreviated to YKW).

The blinkered muggles have, as in years past, attributed the inexplicable deaths associated with the Avada Kedavra curse to known muggle human diseases and have linked the excruciating pain associated with the Cruciatus curse to existing pain syndromes. Worse, aspersions have been cast by muggle healers that such patients are insane and their pain psychogenic. 
While studying for a TOAD (terribly difficult tests of the occult arts leading to a doctorate in magic) at St. Mungo's Hospital for Magical Maladies, we collaborated with the inestimable Madam Poppy Pomfrey. Realizing the benefits of investigating magical and nonmagical maladies afflicting muggle folk (MF) and wizarding folk (WF) alike, we reported muggle corollaries for magical ailments seen in MF and WF at both the Hogwarts Infirmary and St. Mungo's Hospital.

Although we were initially bemused by "ethical considerations" and the emphasis in muggle medicine on "evidence-based" medicine, we soon realized that there was something to be learned from muggle healing arts. The Rowling chronicles abound with instances when magical folk have applied spells or charms to the unwary witch, wizard or muggle, but little has been done to provide guidelines for the ethical use of magic.

Interestingly, Ministry of Magic archives indicate that the only call for "ethical behaviour in wizards" was sponsored by Lucius Malfoy, after his son Draco was turned into a ferret by Bartemius Crouch Junior. Of course, the paper received little support, as young Draco had, it was generally held, been hoist by his own petard after having drawn wands against an unwary Harry Potter. ${ }^{4}$

Be that as it may, we hereby describe case studies in an attempt to provide guidelines for the ethical application of the healing arts to patients who seemingly present with wizard afflictions. We encourage MF and WF healers to contribute their 5 sickles' worth to the discussion on the advantages of collaborative practice.

\section{Muggle ethics}

Muggle ethics are confusing, to say the least. Going back eons and laden with calls to "do good by your fellow man," muggles do not appear to have heeded their own injunctions, preferring instead to "get 'em before they get you" or demand their "pound of flesh" for wrongdoing.

Even the field of medical ethics is mired in controversy. The field is predicated on the dictum "primum non nocere," which YKW would do well to adopt as his personal motto. With beneficence as the foundation for muggle healing, it would appear that muggle medicine advocates helping one's fellow man (or wizard), even at personal cost. Hence, just as muggle healers would not hesitate to roll up their sleeves in a medical emergency, so must we magic healers hitch up our robes and help out when confronted with a medical/magical emergency, where life or limb are at risk. Of course, as has been demonstrated by the befuddled Lockhart, ${ }^{2}$ the prerequisite for lending a hand (or healing a fractured hand) is competence in the healing arts, rather than a mere belief in one's omniscience.

The moral imperative is, of course, not necessarily a legal one. Even when dealing with clear-cut emergencies involving life-or-death situations, muggle healers have been criticized for failing to care for their patients without the means to pay for treatment. Strangely, despite the moral compulsion to treat all comers, muggle healers in some parts of the world are not legally obligated to "assist others in need unless they are already contracted patients of record."

Non-emergency situations are wont to cause even more confusion. Although trainee muggle healers are taught to recognize ailments (thyrotoxicosis, acromegaly, gigantism, chorea and dystonia, to name a few) at a glance, the nonemergent nature of such ailments renders the diagnostic skills of the healer moot. The muggle is forced to content himself with recognizing the condition, while mutely wishing he could hint to the afflicted that "I know what you have, but I can only help you if you ask for my advice," lest unsolicited advice be misconstrued as "advertising," "self-promotion" or, worse, "ambulance chasing." (Note to magical readers: an ambulance is an interesting muggle contraption that transports muggles from the point of illness to the place of healing. Think of it as a nonmagical Knight Bus. ${ }^{3}$ ) Even with the offer of free treatment or care at the hands of another (muggle or wizard) healer, the erstwhile Good Samaritan runs the risk of being charged with "invasion of privacy." The decision to speak out can always be rationalized (e.g., the thyrotoxic patient runs the risk of developing life-threatening atrial fibrillation), but it is clear that clear guidelines are required, both in the muggle and wizarding worlds.

While at St. Mungo's, we were struck by the number of people (healers and lay-wizards alike) who suffered from hitherto undiagnosed conditions. Wizard healers, unaccustomed to muggle ailments such as Tourette's syndrome, failed to identify it in 2 of their number, who spent much of their time fidgeting, writhing and grunting expostulations. One of them had attributed the ailment to having been cursed as a child with the Imperius curse by YKW. How simple it would have been for us to point the way to a neurology text book, but being cross-trained in both the muggle and magical healing arts rendered us uncertain of our moral stance, and thus mute.

\section{Case studies: To interfere or keep silent, in fear?}

Incorporating muggle ethics in this report, we have obtained "informed consent" from our subjects, who have allowed the revelation of their identities. Searching the Pomfrey database, the Rowling chronicles and our own report, ${ }^{7}$ we identified wizarding folk with recognizable ailments, obtained consent to perform the study from our magical IRB (wIzard oveRsight Branch) and set out the study parameters.

\section{Cases 1 and 2: gigantism}

Hagrid and Madame Maxime "stood out" in the Rowling chronicles for their remarkably tall statures. Rubeus Hagrid, we noted, had a strong family history of gigantism, including his mother and half-brother. His relatively short stature (by 
giant standards) was explained by his being only half-giant. We diagnosed constitutional/familial gigantism in him, and turned our attention to Madame Maxime, who denied vociferously having any giant lineage. In view of the lack of family history, we offered to assay her blood for growth hormone and insulin-like growth factor I. Surprisingly, she assented. When these results, including an oral glucose tolerance test, proved to be well within normal limits (for size), we sought clarification from the tearful patient, who pronounced us "'orrible," before admitting "zat her muzzer was, indeed, a giant." Fears that Madame Maxime would complain to the Ministry of Magical Healing that we had overstepped our bounds proved groundless, and she thanked us for "'elping her to admit to zis shameful zecret," after which she agreed to serve as ambassador to the giants.

\section{Case 3: The squib}

Argus Filch seemed, to all intents and purposes, a squib (i.e., WF with a lack of wizarding abilities). Having obtained test kits for determining wizarding genes from Craig and colleagues, ${ }^{9}$ we approached him with a view to testing him for a deletion in the wizarding gene. He was initially loathe to prove that he "might as well be a muggle," but upon hearing that he might spare his children the condition, he agreed "for Mrs. Norris' sake," (which, frankly, made us all a little worried, as Mrs. Norris is his cat). The gene probe showed the presence of both wizarding genes with a nucleotide substitution, which results in a deficiency of the amino acid potterine. Administration of this amino acid has since restored his magical abilities, and he will no doubt feature prominently in a future instalment of the Rowling chronicles. We approached another squib-like personage, who seemed keen, but his decision to undergo genetic testing was vetoed by his grandmother who was sporting a green dress and a tall hat replete with stuffed vulture. ${ }^{3}$

\section{Case 4: Thin, cognitively impaired lady with bulging eyes}

We felt that Sybil Trelawney had been misjudged. Rowling's description of a "very thin woman" with "eyes too large for her face" and cognitive impairment ${ }^{3}$ bade us test her for excessive thyroxine production. With sky-high thyroid receptor antibody, thyroid-stimulating hormone and thyroxine levels, we positively identified Graves' disease with thyrotoxic mania and commenced treatment with carbimazole. Six months after starting therapy, she became hypothyroid after drinking some of Madam Rosmerta's butterbeer, which turned out to contain trace levels of propylthiouracil. Interestingly, she had consumed butterbeer on the 2 occasions that she made accurate predictions. Abilities restored, Professor Trelawney re- signed from Hogwarts and can now be seen on the Psychic Network in America.

\section{Discussion}

The outcomes of our 4 case studies demonstrate the benefit gained from intervention by muggle healers in certain wizard cases to explain aberrant behaviour or disability. In all cases, said intervention resulted in return to (what passes for) normalcy.

Although the small number of subjects in our limited study do not allow for generalization of our findings, they certainly argue that limited interference on the part of healers might not be unwelcome. Recognizing the potential strengths of collaboration between practitioners of magical and muggle healing arts, we are proud to announce the Poppy Pomfrey Chair of Mugical (or Maggle) Medicine, to be conducted at the National University Hospital of Oriental Magic and St. Mungo's Hospital for Magical Maladies.

We encourage healers, MF and WF alike, to use our findings and continue to explore the ethical considerations involved in treating the "well" sick, as well as the role of muggle healing in magical communities and vice versa. We conclude that the Good Samaritan clause should not merely be applied to emergency situations, and that all medical/magical interventions, if beneficent in intent, can only result in good outcomes. With YKW and his followers roaming the streets of both worlds, at liberty to perform nefarious deeds, it would be prudent to allow the wizard (or muggle) on the street to walk up to the confounded, charmed or cursed being and say, "I can tell by your two noses that you've been cursed, mate. Let me get you some help!" To all of you, we say: go forth, and do good! Slainte!

\section{Erle C.H. Lim \\ Amy M.L. Quek \\ Raymond C.S. Seet \\ National University Hospital \\ Singapore}

This article was not peer reviewed, because we only have muggles in our database.

\section{REFERENCES}

I. Rowling JK. Harry Potter and the philosopher's stone. London: Bloomsbury; 1997. 2. Rowling JK. Harry Potter and the chamber of secrets. London: Bloomsbury; I999.

3. Rowling JK. Harry Potter and the prisoner of Azkhaban. London: Bloomsbury; 2000.

4. Rowling JK. Harry Potter and the goblet of fire. London: Bloomsbury; $200 \mathrm{I}$.

5. Rowling JK. Harry Potter and the order of the phoenix. London: Bloomsbury; 2003.

6. Rowling JK. Harry Potter and the half-blood prince. London: Bloomsbury; 2005.

7. Lim EC, Pomfrey PM, Quek AM, et al. Interesting in- and outpatient attendances at Hogwarts Infirmary and St. Mungo's Hospital for Magical Maladies. Ann Acad Med Singapore 2006;35:127-9.

8. Welie JV. Towards an ethics of immediacy. A defense of a noncontractual foundation of the care giver-patient relationship. Med Health Care Philos 1999;2:II-9.

9. Craig JM, Dow R, Aitken M. Harry Potter and the recessive allele. Nature 2005;436:776. 